\title{
A ROCHELA DO BRASIL: SÃO PAULO E A ACLAMAÇÃO DE AMADOR BUENO COMO ESPELHO DA REALEZA PORTUGUESA ${ }^{1}$
}

\author{
Rodrigo Bentes Monteiro \\ Doutorando Depto. de História-FFLCH/USP
}

\begin{abstract}
RESUMO: A aclamação de Amador Bueno da Ribeira em 1641 foi negligenciada em estudos mais recentes, talvez pelo fato de sua história ter sido construída com base em documentos insuficientes. Entretanto, este episódio pode ser recuperado como representativo de uma situação regional particular do planalto paulista, em relação a um conjunto mais amplo de fatores. Deste modo é possível conceber o evento em questão como historicamente provável, pois a aclamação de Amador Bueno apresenta uma intrigante coerência com determinado momento histórico vivido pela dinastia bragantina quando de sua ascensão ao trono de Portugal. A situação - caracterizada em linhas gerais pela fragilidade política - se refletiria por sua vez nos vínculos desta nova realeza lusitana com os seus vassalos, tanto do Reino quanto do ultramar americano.
\end{abstract}

PALAVRAS-CHAVE: Aclamação - Amador Bueno - São Paulo - Restauração - realeza portuguesa - Dinastia Bragança. ABSTRACT: The acclamation of Amador Bueno da Ribeira in 1641 has been neglected in most recent studies, perhaps due to the fact that its history has been built upon insufficient documents. However, this episode may be recovered as representative of a particular regional situation of the "Paulista" plateau in relation to a wider set of factors. In this way, it is possible to conceive the event in question as historically probable, since the acclamation of Amador Bueno presents an intriguing coherence with a certain historical moment lived by the "Bragantina" dinasty at the time of its ascension to the throne of Portugal. The situation - characterized, in general terms, by a political frailty - would reflect on the bonds of the new Lusitana royalty with its vassals in the kingdom as well as in the overseas America.

KEYWORDS: Acclamation, Amador Bueno, São Paulo, Restauration, Portuguese Royalty, Bragança Dinasty.

${ }^{1}$ Este artigo foi originalmente concebido como primeiro capítulo de minha tese de doutorado em História Social apresentada ao Departamento de História da Faculdade de Filosofia, Letras e Ciências Hu- manas da Universidade de São Paulo em marco de 1999, sob orientação da professora Laura de Mello e Souza. O texto foi reduzido e algumas notas foram suprimidas (BENTES MONTEIRO, 1999). 


\section{O aclamado}

Em sua primeira fala do trono durante a Assembléia Constituinte de 1823, D. Pedro I comentava os motivos que o tinham levado a São Paulo em setembro do ano anterior, ainda como príncipe regente do Brasil. Ele destacava aquele lugar como o primeiro no qual nossa independência foi proclamada, "no sempre memorável sítio da Piranga", para em seguida dizer: "Foi na pátria do fidelíssimo, e nunca assaz louvado Amador Bueno de Ribeira, onde pela primeira vez fui aclamado Imperador." (FALAS DO TRONO, 1889, p.14). Aproximadamente vinte e cinco anos mais tarde Francisco Adolfo de Varnhagen dedicava a D. Pedro II uma peça de teatro intitulada Amador Bueno ou A Coroa do Brasil em 1641, e escrevia em sua dedicatória: "Senhor: o assunto desta composição envolve o pensamento da unidade do Brasil em virtude da aclamação geral nele da Casa de Bragança - V. M. I., hoje representante desta casa e símbolo da integridade do Império, a honraria sobremaneira dignando-se de ser dela indulgente protetor. - Seja-o, Senhor! - E outorgue V. M. I., desta forma, sua alta proteção ao autor - De V. M. I. - súdito fiel e humilde. Beijando reconhecido a augusta mão do mecenas soberano que propiciamente acolheu o pensamento desta composição (...) do grande feito tradicional de 1641, que se associará para sempre à Coroa do Brasil." (VARNHAGEN, 1858) ${ }^{2}$.

No discurso de D. Pedro I a terra de S. Paulo era valorizada enquanto lugar primeiro da independência por ter sido também a terra de Amador Bueno. Esta lembrança era feita em 1823, num tempo em que a libertação em relação a Portugal ainda era uma questão duvidosa em várias províncias, onde "brasileiros"

\footnotetext{
${ }^{2}$ Em 1847 fez-se uma edição do drama teatral em Lisboa, sendo publicado pela segunda vez em Madri, edição da qual se retirou a citação. Em 1864 a obra foi readaptada e publicada no Rio de Janeiro.
}

e tropas portuguesas entravam em conflito. Por sua vez, na dedicatória da peça teatral, o Imperador do Brasil era visto como símbolo da integridade do Império. O historiador Varnhagen reconhecia em D. Pedro II o representante da casa dos Bragança, estabelecendo uma relação entre a unidade do território brasileiro e a autoridade do monarca. Tal observação era feita em meados do século XIX, após um conturbado período regencial repleto de idéias federalistas expressas em movimentos provinciais que colocavam em dúvida o poder central no país. Representava assim a antecipação da maioridade em 1840 uma volta ao princípio centralizador e à ordem promovida pela ação "pacificadora" das tropas imperiais nas províncias rebeldes. Esta relação entre o poder do soberano e a manutenção da integridade territorial era estabelecida pela figura enaltecida do Imperador e pela lealdade de seus súditos. Varnhagen relacionava a permanência desta autoridade unificadora no Brasil do século XIX ao passado colonial americano, em seu aspecto de sujeição ao rei português da dinastia Bragança, dinastia da qual descendia D. Pedro II. Tais idéias foram desenvolvidas pelo autor mediante a recuperação do exemplo dignificante de Amador Bueno.

Mas que história é esta recuperada pelo primeiro imperador, e trabalhada pelo visconde de Porto Seguro mais de dois séculos depois de acontecida? Embora permaneça até hoje presente na memória nacional, é ao mesmo tempo muito pouco compreendida. Em que espécie de contexto ela surgiu? Certamente as breves considerações aqui tecidas não conseguirão resolver as dúvidas referentes a um assunto tão controvertido na historiografia brasileira. No entanto, o episódio do vassalo paulista que preferiu a soberania portuguesa - em vez de comandar um movimento separatista - no momento da ascensão dos Bragança ao trono lusitano tem grande valor neste estudo.

O principal relato envolvendo a aclamação de Amador Bueno é o de Frei Gaspar da Madre de Deus, em suas Memórias para a História da Capitania de 
São Vicente. Acompanhemos o resumo de sua narrativa, a partir da chegada em São Paulo da notícia de que o duque de Bragança havia sido aclamado rei na capital São Vicente, com o nome de D. João IV.

Frei Gaspar escrevia que essa novidade fora um golpe duro para os espanhóis, que se achavam estabelecidos e casados na vila de São Paulo, vindos da Europa e das Índias Ocidentais. Eles desejavam conservar as povoações acima da Serra na obediência de Castela, "e não se atrevendo a manifestar seu intento, por conhecerem que seriam vítimas sacrificadas à cólera dos paulistas, (...) resolveram entre si usar de artifício" (MADRE DE DEUS, 1975, p.138-141). Os espanhóis achavam que a capitania de São Vicente "e quase todo o sertão brasílico" seriam reunidos à posse de Espanha, se os paulistas se desmembrassem de Portugal. Deste modo, "fingindo-se penetrados do amor ao país onde estavam naturalizados e do zelo do bem comum, propuseram aos seus amigos, parentes, aliados e a outros, um meio que lhes pareceu o mais seguro, para conseguirem os seus intentos: tal era o de elegerem um rei paulista; e ao mesmo tempo apontaram como o mais digno da Coroa a Amador Bueno de Ribeira". Justificava-se a escolha do aclamado por ser ele "de qualificada nobreza e de muito respeito e autoridade pelos empregos públicos que havia ocupado e ainda exercia, pela sua grande opulência, pela roda de parentes, e amigos." Os espanhóis então se teriam valido de todos os argumentos possíveis para persuadirem os "paulistas e europeus pouco instruídos", que eles podiam não reconhecer por soberano um príncipe a quem ainda não tinham jurado obediência, "sem encargo de suas consciências, nem faltarem à obrigação de honrados e fiéis vassalos"; incentivaram a vaidade dos ouvintes, exagerando o merecimento dos paulistas e europeus, dizendo que suas qualidades pessoais e de nobreza "os habilitavam para maiores impérios". Lembraram ainda os milhares de índios e escravos que controlavam, podendo formar "exércitos formidáveis" favorecidos pela situação de São Paulo, "tão vantajosa nesse tempo, que (...) bastaria lançarem-se pedras pela serra abaixo, para se retirarem os expugnadores". Amador Bueno teria ficado pasmo ao ouvir estas proposições, lembrando aos demais "a obrigação que tinham de se conformarem com os votos de todo o Reino e a ignomínia de sua Pátria, se não reparasse a tempo com voluntária e pronta obediência o desacerto de tão criminoso atentado". Mas a rejeição do eleito teria aumentado a vontade do povo "ignorante", que chegou a ameaçá-lo de morte se não quisesse "empunhar o cetro". Amador Bueno então, "fiel vassalo", saiu de sua casa escondido com a espada na mão, caminhando apressado para o mosteiro de São Bento, em busca de refúgio. Mas "todos corriam após ele, gritando: viva Amador Bueno, nosso rei: ao que ele respondeu muitas vezes, em voz alta: viva o Senhor D. João IV, nosso rei e senhor, pelo qual darei a vida." Chegando Amador Bueno ao mosteiro, fechou rapidamente as portas, mandando chamar os eclesiásticos mais respeitáveis, "e todos unidos ao dito Bueno fizeram compreender aos circunstantes que o Reino pertencia à Sereníssima Casa de Bragança e que dele se acharia esta em posse pacífica desde o dia da morte do cardeal rei D. Henrique, se a violência dos monarcas espanhóis não houvera sufocado o seu direito." Os "fiéis portugueses" conduziram-se assim como deviam: todos "arrependidos do seu desacordo", foram "cheios de gosto" aclamar solenemente D. João IV, com mágoa dos espanhóis, que "para não perderem as comodidades que tinham vindo procurar em S. Paulo", prestaram também juramento de fidelidade ao mesmo rei.

Frei Gaspar da Madre de Deus (1715-1800) viveu entre Santos, onde nasceu, Rio de Janeiro e São Paulo, tendo chegado ao cargo de abade provincial na capital do Vice-Reino em 1766. Interessado pela pesquisa histórica nos arquivos então existentes, foi autor de várias obras sobre as localidades nas quais habitou, sendo a mais significativa delas as suas $M e-$ 
mórias (...) de São Vicente. Frei Gaspar exaltava nas memórias que escrevia o heró́smo dos primeiros povoadores vicentinos, ligados às mais expressivas famílias da capitania, das quais descendia o monge. Nesse sentido, geralmente eram buscadas origens nobres européias nesses principais troncos familiares $^{3}$. Esta tendência de valorização dos antepassados vicentinos segundo a lógica européia, e das aventuras bandeirantes seiscentistas no século XVIII, estava de acordo com o processo de sujeição dos paulistas à colonização portuguesa, principalmente depois do início da exploração do ouro nas Minas e a criação da capitania de São Paulo em 1720. Frei Gaspar era um eclesiástico de expressão na América portuguesa em meados dos setecentos, e como tal recuperava este passado paulista não somente destacando a sua "nobreza" de sangue e de valores, mas também a obediência daqueles habitantes às ordens vindas de Portugal. Desta forma é contado o episódio envolvendo a aclamação de Amador Bueno em São Paulo, 1641. Obra dos espanhóis, que tramaram com "artifício" para iludir os "paulistas e europeus pouco instruídos" que, mesmo apoiando a aclamação, foram considerados pelo memorialista "honrados e fiéis vassalos", ou "fiéis portugueses", permanecendo, depois da recusa de Amador Bueno, "arrependidos do seu desacordo".

Em seu afã na busca e no estudo das origens, Frei Gaspar correspondia-se com o amigo e primo Pedro Taques de Almeida Leme (1714-1777), que ocupou vários cargos administrativos e militares de relativa expressão entre São Paulo e Minas a partir de 1737, e era igualmente identificado com o enaltecimento do passado. Taques construiu a sua Nobiliarquia Paulistana..., a partir das informações encontradas em cartórios seculares e eclesiásticos da capitania de São Paulo e suas vizinhas. Como parte desta genealogia

\footnotetext{
${ }^{3}$ Sobre a súmula biográfica de Fr. Gaspar, conferir o estudo introdutório de Afonso Taunay (MADRE DE DEUS, 1975, p.138-141).
}

compôs em 1742 a história dos Buenos, narrando o feito da aclamação:

"Foi Amador Bueno vassalo de tanta honra e fidelidade que, enchendo-se na sua maior opulência de cabedais, respeito e estimação, com dois genros castelhanos, ambos irmãos e fidalgos ambos, que tinham poderoso séquito dos espanhóis, casados e estabelecidos em S. Paulo, com aliança das famílias mais principais da capitania; não podendo estes castelhanos suportar a gloriosa e feliz aclamação do Sr. Rei D. João IV de Portugal, e $2^{\circ}$ do nome entre os sereníssimos duques de Bragança, formaram um corpo tumultuoso, e as vozes aclamavam por seu rei a Amador Bueno, intentando vencer com este bárbaro e sacrílego atentado a constância do honrado vassalo Amador Bueno, para deste modo evitarem a obediência e o reconhecimento de que se devia dar ao legítimo rei e natural senhor, ficando S. Paulo com a voz de Castela, assim como estiveram os moradores da Ilha Terceira até o ano de 1583 com a do Sr. D. Antônio, Prior do Crato, que se achava refugiado em França (...) Tinha o corpo da rebelião adquirido força nos autores dele, os castelhanos, que por si e suas famílias avultavam em grande número. (...) Porém Amador Bueno, sem temer o perigo nem deixar prender-se da indiscreta lisonja, com que lhe ofereciam o título de rei para o governo dos povos da capitania de S. Paulo, sua pátria, soube desprezar, e ao mesmo tempo repreender a insolente aclamação, desembainhando a espada e gritando a vozes: - 'Real, real por D. João IV, rei de Portugal' - Salvou a vida do perigo em que se viu pelo corpo desta horrorosa sedição, recolhendo-se ao sagrado mosteiro de S. Bento, acompanhado dos leais portugueses europeus e paulistas até ficar em sossego o inquieto ânimo dos castelhanos que tinham fomentado o tumulto. Nesta ação deu inteiramente créditos de si a incontrastável lealdade deste vassalo paulista" (LEME, 1980, p.76-78).

De forma mais enfática ainda do que no relato de Frei Gaspar, esta narrativa de Pedro Taques responsabiliza os espanhóis pela formação do "corpo tumultuoso" no "bárbaro e sacrílego atentado", omitindo qualquer participação paulista na "horrorosa sedição", sendo referidos somente os que apoiaram a recusa do aclamado, qualificados como "leais portugueses europeus e paulistas". Aparecem destacadas também a "honra", "fidelidade", "lealdade" do vassalo Amador Bueno, ao lado de uma certa imprecisão ao mencio- 
nar-se a hipótese de sua aclamação, quando escreve "ficando S. Paulo com a voz de Castela". É relevante também no relato a comparação deste evento com determinado episódio da história de Portugal, a aclamação de D. Antônio Prior do Crato, e a existência de uma fórmula comum de "aclamação" no império lusitano, caracterizada pela expressão "real, real", que teria sido proferida por Amador Bueno, segundo o autor ${ }^{4}$.

Os documentos que comprovam os relatos expostos são os mesmos. No livro de registros do arquivo da Câmara da vila de São Vicente está a patente de capitão de reformados fornecida por Arthur de Sá, governador da Repartição Sul a Manoel Bueno da Fonseca, neto do aclamado, em 1700, na qual declara a lealdade de Amador Bueno. Esta patente foi confirmada pelo rei de Portugal D. Pedro II em 1701, também registrada em São Vicente: “... e quando não bastavam estes serviços era merecedor de grandes cargos, por ser neto de Amador Bueno que sendo chamado pelo povo para o aclamarem Rei obrando com leal e verdadeiro vassalo com evidente perigo de vida, exclamou dizendo que vivesse El-Rei Dom João o quarto seu Rei e Senhor que pela fidelidade que devia de vassalo queria morrer nessa defensa e respeitando eu neste tão louvável vassalo digno de grande remuneração hei por bem nomear". Manoel Bueno ainda teria recebido o hábito de cavaleiro da Ordem de Cristo do rei D. João V, que mencionou em carta

\footnotetext{
${ }^{4}$ A aclamação do Prior do Crato é estudada em outro capítulo de minha tese (BENTES MONTEIRO, 1999, p.42-48). Observe-se no entanto a comparação feita por Taques entre São Paulo e os Açores, que permaneceram com D. Antônio até sua capitulação frente aos Habsburgo (BERCÉ, 1990, p.17-81). A fórmula comum da aclamação, ainda que inventada por Taques no século XVIII, denotava uma correspondência entre a prática política no Reino e na América portuguesa, pois os reis lusos tendiam a ser aclamados e não coroados (BRÁSIO, 1989, p.34-43, e BETHENCOURT e CURTO, 1991, p.187-200).
}

justificando a concessão: - "Por ser neto do meu muito honrado e leal vassalo Amador Bueno" (LEME, 1980, p.78, \& MADRE DE DEUS, 1975, p.141-142). Observamos que Madre de Deus e Taques situam a concessão do hábito por parte de D. João V ao neto de Amador Bueno em 1704, quando sabemos que este rei governou de 1707 a 1750. Logo, o rei correto seria D. Pedro $\mathrm{II}^{5}$.

Os dois escritores setecentistas foram contestados. Na segunda metade do século XIX o senador Cândido Mendes de Almeida escrevia sobre a mania nobiliárquica que atacou os autores em questão, pondo em dúvida o passado heróico de seus ascendentes, repleto de invenções e fantasias, fruto de uma vaidade atávica. Esses argumentos foram reforçados por nomes como José Veríssimo e Moreira de Azevedo. Este último escreveu um artigo, com base em pesquisas no arquivo da Câmara de São Paulo, afirmando que Frei Gaspar forjou certo documento relativo à aclamação de Amador Bueno, mais especificamente, à patente passada por Arthur de Sá ao neto do aclamado, concluindo então que "não há documento algum que prove a aclamação e recusa da coroa por Amador Bueno, sendo este fato apenas uma tradição" (apud TAUNAY, 1926, p.222-228).

A palavra tradição também foi utilizada num parágrafo dubitativo de Varnhagen em sua História Geral do Brasil, ao escrever sobre a aclamação de D. João IV nas vilas da capitania vicentina: “Teve assim lugar a aclamação, alguns dias depois, nas vilas de Santos e São Vicente; a de São Paulo não se apressou, para o que bastaria terem-lhe sido as ordens comunicadas pelo governador Salvador Correia, com quem estava em guerra aberta. Se acreditarmos na

\footnotetext{
${ }^{5}$ No arquivo da câmara da vila capital de São Vicente, livro 1684 1702, p. 125, se acharia a patente de Arthur de Sá a Manoel Bueno da Fonseca, confirmada por D. Pedro II em 23 de Novembro de 1701, registrada em São Vicente no livro 1702, p.1.
} 
tradição, que no século passado recolheu um monge beneditino, filho da província, houve até o pensamento de independência; e ao tratar-se de o realizar não se levou a efeito pela abnegação de Amador Bueno, a quem foi oferecida a coroa. (...) Ante o fato (se realmente sucedeu) da rejeição de uma coroa neste Estado, ainda então nas faixas da infância, não sabemos qual admirar mais, - se o juízo são do que descobriu que tal coroa não podia então ser perdurável, (...) se a abnegação do homem desambicioso, que sacrificou sua elevação no altar da pátria, evitando o fracionamento desta, ou pelo menos poupando-lhe uma sanguinolenta guerra civil." (VARNHAGEN, 1981, p.131).

Em sua História Seiscentista da Vila de São Paulo, Afonso Taunay defendia a validade dos escritos de Frei Gaspar, destacando a confusão feita por Moreira de Azevedo ao pesquisar no arquivo da Câmara de São Paulo em busca da patente de Arthur de Sá, quando deveria ter pesquisado no arquivo da Câmara de São Vicente, de acordo com as indicações do memorialista. Após achar o documento procurado na antiga capital vicentina, o autor busca a comprovação no Arquivo Nacional do Rio de Janeiro, verificando uma diferença ínfima entre o texto apresentado pelo eclesiástico e a cópia documental daquele acervo (TAUNAY, 1926, p.222-232). Embora tenha sido um eficiente confrontador de fontes históricas, Taunay, escrevendo na primeira metade do século XX, estava longe de esconder sua parcialidade em relação ao tema. Investia contra os que atacaram Pedro Taques e Frei Gaspar, citando os historiadores e viajantes que concordaram com a versão apresentada pelo memorialista vicentino. Identificava-se com os contemporâneos Alfredo Ellis Jr. e Aureliano Leite, que também foram autores de obras sobre o assunto, preocupavase com a possível data da aclamação de Amador Bueno e, de um modo que não mais o setecentista, exaltava os valores e o passado da gente paulista. (TAUNAY, 1926, p.236-238, ELLIS JUNIOR, 1937 e 1948, e LEITE, 1940, p. 549-567) ${ }^{6}$.
Esta atitude por demais apaixonada na valorização da história de sua terra, ainda que combinada a uma atividade reflexiva e de pesquisa, reproduzia o "fidalguismo" já existente nos escritos de Frei Gaspar, sobretudo nos de Pedro Taques. Em seu livro Portugal na Época da Restauração, Eduardo d'Oliveira França afirma que a nobreza portuguesa, embora dependesse das rendas vindas do ultramar, não estava muito interessada nos problemas ultramarinos. A fidalguia lusitana não se transportou de maneira significativa para a estruturação das sociedades no Novo Mundo. Deste modo os "fidalgos coloniais" seriam homens que tinham ascendido pela posse da terra e da riqueza, obtendo privilégios significativos, e para os quais acabaram-se descobrindo parentescos nobilitantes. Em relação à América portuguesa, os linhagistas descobriram brasões duvidosos para esses potentados da terra, que certamente também ansiavam por serem considerados nobres. A comprovação desta precariedade encontrada nas linhagens de nobrezas coloniais pode ser verificada pela completa ausência de títulos. Nas palavras do historiador: "Onde a titulatura colonial? Afidalgaram-se sem títulos os senhores de terras: os títulos - marca da nobreza - são manufaturados em cortes, onde há rei." (FRANÇA, 1997, p.184-185). Também segundo Oliveira França, o próprio Ellis Júnior, pela análise de

\footnotetext{
${ }^{6}$ Robert Southey, Rocha Pombo e Saint-Hilaire aceitaram o relato de Frei Gaspar sobre a aclamação de Amador Bueno segundo Taunay, que também faz referência à postura ambígua de Varnhagen e à omissão de Capistrano de Abreu. Quanto à data de aclamação de A. Bueno, especulada por Taunay e Ellis Jr, sabe-se que a notícia da restauração portuguesa foi recebida na Bahia em fevereiro de 1641 e no Rio de Janeiro em 10 de março. Dias depois a aclamação aconteceu em Santos e em São Vicente. A hipótese dos autores é a de que a aclamação de A. Bueno teria acontecido da segunda quinzena de março até 3 de abril de 1641, data da aclamação de D. João IV em São Paulo (VARNHAGEN, 1981, p. 130-131, e TAUNAY, 1926, p. 239-243).
} 
inventários e testamentos que verificavam a procedência dos povoadores paulistas, deixava evidente que eles vinham sobretudo do sul de Portugal, deslocados do centro cortesão do reino. Gilberto Freyre por sua vez questionaria a validade das genealogias pernambucanas repletas de fidalguismo, em Casa Grande \& Senzala. Assim é que nos aproximamos da análise de Evaldo Cabral de Mello sobre um sistema de fraude genealógica ocorrido na capitania de Pernambuco, procurando mascarar as origens de cristão-novo de Filipe Pais Barreto, senhor de engenho candidato em 1700 ao título de cavaleiro da Ordem de Cristo, concedido pelo rei. Como ao neto de Amador Bueno (FREYRE, 1988, \& MELLO, 1989).

Este processo de nobilitação dos antepassados, mais tardio em São Paulo do que em Pernambuco, pode ser relacionado à introjeção natural dos valores portugueses nas sociedades regionais ultramarinas, decorrente do avanço do processo colonizatório. Mas o enobrecimento também poderia ser lido num sentido inverso, como afirmação de uma elite local face ao poder soberano, o que se aplicaria ao caso de Amador Bueno, ou da imagem construída pela historiografia paulista sobre este episódio. Existia assim uma habitual confusão criada entre os estatutos de "homem bom" e "fidalgo", pois todo fidalgo, à medida que podia participar da vida política municipal, era um homem bom, e no entanto o inverso não acontecia na mesma medida, por se depender do sangue ou da concessão régia (FRANÇA, 1997, p.185-186).

A identificação excessiva com o passado paulista no sentido de seu enaltecimento e nobilitação, produzida nos séculos XVIII ou XX, pode ter assustado outros historiadores, que se esquivaram sutilmente a tratar do assunto em questão. Em Salvador de Sá e a Luta pelo Brasil e Angola, Charles Boxer escreve sobre a aceitação de D. João IV no Rio de Janeiro, e a seguir comenta: "No dia seguinte a notícia foi mandada para Santos, São Paulo e outros lugares das capitanias de baixo, com ordem de seguir o exemplo do
Rio e da Bahia. (...) Em São Vicente, todas as cercanias obedeceram às suas ordens, embora diga a tradição que em São Paulo se esboçara um movimento de oposição, levantado pelos partidários da Espanha, que tentaram proclamar um dos seus, Amador Bueno, chefe de uma monarquia independente, com sede no planalto. Esse incidente foi apenas passageiro visto que São Paulo não tardou a seguir o exemplo dado pelo Rio, declarando-se a favor de D. João IV.” E ainda acrescenta em nota: "No Brasil tem-se gasto uma despropositada quantidade de tinta com o caso em questão, aliás relativamente insignificante" (BOXER, 1973, p.160-161).

Por sua vez, interrogando-se sobre as características diferenciadas das colonizações portuguesa e espanhola na América, Sérgio Buarque de Holanda escreve: "A obra das bandeiras paulistas não pode ser bem compreendida em toda a sua extensão, se a não destacarmos um pouco do esforço português, como um empreendimento que encontra em si mesmo sua explicação, embora ainda não ouse desfazer-se de seus vínculos com a metrópole européia, e que, desafiando todas as leis e todos os perigos, vai dar ao Brasil sua atual silhueta geográfica. Não é mero acaso o que faz com que o primeiro gesto de autonomia ocorrido na colônia, a aclamação de Amador Bueno, se verificasse justamente em São Paulo, terra de pouco contato com Portugal e de muita mestiçagem com forasteiros e indígenas" (HOLANDA, 1986, p.68).

Estudando a questão da escravidão indígena na capitania e os conflitos entre paulistas e jesuítas no contexto da Restauração portuguesa, John Monteiro sugere a possibilidade de um vínculo entre a expulsão dos padres desta ordem de São Paulo e a Restauração dos Bragança: "Portanto, não é inteiramente implausível a ligação entre a expulsão, a Restauração e a suposta aclamação de Amador Bueno, a despeito dos esforços de Taunay e Aureliano Leite em afastar qualquer hipótese nesse sentido. De qualquer modo, fica claro que o motivo básico sustentando as ações dos 
colonos foi a questão indígena" (MONTEIRO, 1995, p. 251-252).

Apesar do relativo laconismo e da escassez de mais informações, o caminho para a investigação está traçado. Trata-se, agora, de procurar perceber o contexto paulista e da capitania de São Vicente no século XVII, sem dirigir tanta atenção à história ou aos feitos de personagens heroicizadas, mas principalmente a outras circunstâncias e características deste mesmo ambiente social, provavelmente relacionadas ao evento que constitui o objeto primeiro deste estudo.

\section{Os paulistas e os índios}

Em meados do século XVI, a capitania de São Vicente era a mais próspera das "capitanias de baixo", que situavam-se no mapa ao sul da capitania do Rio de Janeiro, isto é, Santo Amaro, Nossa Senhora da Conceição de Itanhaém, e a própria São Vicente. Essas capitanias eram tão ligadas por problemas comuns que passaram a ser tratadas administrativamente como um grupo uno, como "capitanias de baixo", ou "capitania de São Vicente". Os habitantes das "capitanias de baixo", em especial os de São Vicente, eram conhecidos como os maiores preadores de índios. $\mathrm{O}$ principal núcleo urbano dessa região era a vila de São Paulo de Piratininga, situada no planalto e alcançada da costa por meio de um difícil caminho pela Serra do Mar. Para conseguirem mão-de-obra em suas plantações e casas, os paulistas organizavam expedições em que entravam centenas de milhas no interior do continente, às vezes ao longo de anos (BOXER, 1973, p. 34-38).

Os paulistas adotaram muitos costumes e peculiaridades das tribos indígenas, inclusive através da mestiçagem. Por essa razão, não raro eram chamados mamelucos pelos estrangeiros. Por vezes eram tão versados no que se refere ao estilo de vida nas selvas quanto os próprios índios por eles submetidos. Por volta do segundo decênio do século XVII, os mestiços de lusos e índios eram maioria na capitania de São
Vicente (HOLANDA, 1986, p.88-96; MONTEIRO, 1995, p.164). Já por volta de 1550, portugueses de São Vicente vendiam escravos índios em Assunção, na província do Paraguai; mas somente a partir de 1620 começaram as grandes expedições e devastações promovidas pelos paulistas, causadas provavelmente pela dizimação ou pelo desaparecimento das tribos mais próximas, nas cercanias de São Paulo (BOXER, 1973, p. 39-43).

No entanto, as numerosas incursões ao interior não se destinavam propriamente ao abastecimento de um suposto mercado de índios no litoral, e sim a suprir uma crescente demanda de trabalho no próprio planalto, para a produção e o transporte de excedentes agrícolas. Desse modo, a região se articulava com outras partes da América portuguesa, e mesmo ao comércio mercantil do Atlântico meridional. Enquanto os historiadores paulistas tradicionais afirmaram que a maior parte desses índios era vendida na região açucareira, John Monteiro demonstra que os cativos índios em maioria seriam utilizados nos trigais, roças e transporte de São Paulo. Somente um número menor desses cativos seria absorvido pelos engenhos fluminenses e nordestinos, cobrindo as falhas do tráfico negreiro transatlântico (MONTEIRO, 1995).

A época áurea da produção de trigo na região de São Paulo foi entre 1630 e 1680. Justamente nesse período, o número de escravos índios chegou a níveis mais elevados, comprovando a relação entre a abundância de mão-de-obra indígena e a agricultura comercial, formando uma economia periférica articulada ao litoral. No início do século XVII, o trigo já integrava o elenco diversificado dos agricultores paulistas como produto de pouca expressão. Mesmo assim era destacado pelo seu valor comercial, destinado à população européia do litoral e às frotas portuguesas. Nunca foi produzido para sustentar a população local, que concentrava o seu consumo na mandioca, no feijão, e sobretudo no milho, formando a chamada "civilização do milho" de Sérgio 
Buarque de Holanda (HOLANDA, 1994, p.181-189). Um agente espanhol que viveu em São Paulo conta que em 1636 a região produziu grande quantidade de trigo e mais hortaliças, mandioca, arroz, algodão e ouro de aluvião. O fato de ter existido em São Paulo durante o século XVII dois ou três ourives e joalheiros demonstra que uma parte da população vivia bem acima dos limites da pobreza. Esta visão da prosperidade de São Vicente é contrária aos estereótipos de que seus habitantes viveriam na pobreza, ou que seriam auto-suficientes, alheios ao que se passava no resto do continente (BOXER, 1973, p.43).

De fato, a propriedade de um moinho de trigo conferia poder e prestígio a indivíduos e famílias paulistas. Os Pires, Bueno e Camargo tinham o domínio sobre vários bairros rurais ao norte da vila de São Paulo. Existia uma forte correlação entre a produção de trigo, a posse da terra pela doação de sesmarias, a posse de cativos índios e a concentração de riqueza entre os moradores de São Paulo, mantendo-se assim as hegemonias e riquezas familiares. Amador Bueno possuía centenas de índios cativos por ele conquistados, que trabalhavam em abundantes culturas de trigo, milho, feijão e algodão, e também criação de porcos, gado, cavalos e ovelhas ${ }^{7}$. A vila de Santos seiscentista possuía um tráfico marítimo irregular, mas era o principal porto de saída das mercadorias de São Paulo, ligando os produtores e comerciantes paulistas às outras capitanias e a Portugal e até Angola. O maior mercado para

\footnotetext{
${ }^{7}$ John Monteiro, ao referir-se ao bairro de Antônio Bueno - Juqueri - diz que suas origens remontam a 1627, quando da concessão de um sesmaria a Amador Bueno da Ribeira. A doação incorporava uma aldeia indígena. Parece pouco provável que Amador tenha ocupado a sesmaria, pois deve ter permanecido em sua fazenda de trigo em Mandaqui, onde com o trabalho das centenas de cativos guarani trazidos do Guairá por seus filhos nas expedições de 1628 32 , tinha abundantes colheitas de trigo, milho, feijão e algodão. O
}

o trigo de São Paulo era o Rio de Janeiro, com sua população de senhores de engenho, mercadores e administradores. Mas havia uma diferença de interesses entre os habitantes da capitania de São Vicente e os de outras capitanias. Enquanto os envolvidos com a plantação de cana-de-açúcar no litoral concentravam seus objetivos no comércio com Portugal pelo Oceano Atlântico, os do planalto voltavam-se para o sertão inexplorado, de forma que foi possível afirmar, utilizando uma metáfora tão paradigmática para a colonização portuguesa na América: "Não é possível imaginar nada mais diferente dos caranguejos de Frei Vicente do que esses paulistas preadores de índios" (BOXER, 1973, p. 40).

A partir da década de 1580, não obstante as restrições impostas pela legislação portuguesa que proibia a escravidão indígena e à medida que se tornava evidente a insuficiência dos aldeamentos jesuítas como forma de suprir a mão-de-obra, os paulistas assumiram a tarefa de obter o trabalhador através das expedições ao interior, diferenciando-se assim do litoral açucareiro, onde a escravidão africana foi preferida. A maioria das expedições possuía como objetivo as aldeias Guarani do Guairá, envolvidas desde meados do século XVI nos conflitos entre espanhóis, portugueses e jesuítas na região. Os povoadores do Paraguai e os portugueses de São Paulo disputavam a apropriação da mão-de-obra neste grande e mal definido território, limite entre os extremos dos impérios de Portu- fato do bairro ter o nome do segundo filho de Amador parece confirmar que o dono original nunca ocupou suas terras, tendo-a adquirido para exploração futura por seus descendentes. A consolidação do bairro deu-se a partir da grande expedição de apresamento de 1666, formada por Amador Bueno, o moço, Antônio Bueno, Baltasar da Costa Veiga (genro de Amador moço) e Mateus de Siqueira, senhores de muitos cativos índios (MONTEIRO, 1995, p.121 e p.197-198, e LEME, 1980, p.75-76). 
gal e Espanha na América meridional. No entanto, nenhuma das duas partes de exploradores estava interessada na ocupação do lugar, querendo apenas os cativos guarani. O período de 1628 a 1641 representou o áuge do apresamento dos Guarani pelos paulistas, devido ao desenvolvimento da economia do planalto, tendo a população da capitania de São Vicente crescido rapidamente neste período devido ao grande fluxo de cativos (MONTEIRO, 1995, p.52-76 e p. 107).

Deste modo, ao longo de todo o século XVII a solução ou "remédio" encontrado pelos jovens paulistas para conseguir alguma posição na sociedade era, através das armações, obter o cativo indígena, pois este oferecia um ponto de partida para as atividades produtivas, bem como uma fonte de renda. Os paulistas podiam ainda servir aos planos da Coroa na busca de metais preciosos, ou ainda prestar serviços militares na defesa do patrimônio açucareiro e pecuário do nordeste. Para os paulistas, o século XVII começou com a convergência entre os interesses minerais e a busca de cativos, e terminaria de forma igual. Até o fim deste século, quando o apresamento foi superado de vez pela mineração, as expedições estavam vinculadas às necessidades do planalto. Antes da destruição sistemática dos Guarani, os paulistas permaneciam restritos à agricultura de subsistência ou à exportação de pequenas quantidades de carne ou marmelada, requerendo pouca mão-de-obra. Com o aumento da população cativa através dos assaltos às aldeias e missões guarani, foram abertas maiores possibilidades de empreendimentos agrícolas, com a exploração dos trabalhadores índios ${ }^{8}$.

\footnotetext{
${ }^{8}$ Segundo Myriam Ellis, o bandeirantismo ofensivo iniciou com a chegada em São Paulo, 1599, de D. Francisco de Sousa, sétimo governador-geral do Brasil (1591-1602). Convicto da ocorrência de riquezas minerais no interior, fez partir de muitos pontos expedições em demanda das pedras e metais preciosos, com divi-
}

Assim, os paulistas eram fornecedores e consumidores no comércio de cativos, e não intermediários, pois o sertanismo não era um negócio no sentido do que se constituiu com o tráfico negreiro. A partir de 1640 iniciou-se uma crise no abastecimento de cativos para a capitania de São Vicente, que foi se agravando paulatinamente, obrigando a adoção de outras atividades como a criação de gado, que requeria menos mão-de-obra. E a viabilidade do esquema de aprisionamento dos índios começava a declinar em vista do aumento das distâncias, da resistência indígena e dos custos envolvidos (MONTEIRO, 1995, p.85-98).

\section{Os paulistas e os jesuítas}

No século XVI, os jesuítas implementaram em São Paulo um projeto de aldeamentos, pretendendo oferecer uma solução para a questão do domínio e do trabalho dos índios. Os colonos da capitania a princípio teriam demonstrado alguma simpatia pelos aldeamentos, desde que estes lhes garantissem mãode-obra farta e barata. Desejavam negociar os serviços diretamente com os índios; no entanto, os jesuítas atuavam sempre como intermediários. Em 1598, com as tensões já se agravando, os principais da terra protestaram na Câmara municipal de São Paulo contra a "grande opressão" que sofriam nas mãos dos jesuítas e das autoridades, que bloqueavam a negociação com os índios aldeados, seus "amigos e vizinhos" (MONTEIRO, 1995, p.42-45).

A partir do princípio do século XVII, a experiência com o trabalho livre havia fracassado em São

sões militares, ouvidores do campo, escrivães, capelães e roteiros preestabelecidos. Após a viagem de D. Francisco de Sousa a Portugal em 1605, os paulistas continuaram o devassamento do sertão, mas em busca do lucro imediato da caça ao índio (HOLANDA, 1985, v.1, p.277 e p.284-285). 
Vicente. O problema maior - reclamavam os colonos - era a falta de confiabilidade da mão-de-obra dos aldeados. Os índios recusavam-se a trabalhar, ou não respeitavam as condições de pagamento, voltando ao aldeamento tão logo recebiam os vencimentos, sem terminar os serviços. Além disso, as doenças e a própria resistência indígena ao aldeamento punham em dúvida o êxito do projeto missionário na região. Nas missões, os jesuítas concentravam seus esforços em três principais linhas de ação: a conversão dos líderes, a doutrinação dos jovens e a eliminação dos pajés. Mas a resistência em maior ou menor grau eliminava a idéia de controle sobre os índios e de prepará-los para a vida produtiva, criando em vez disso comunidades de índios entristecidos e acometidos por doenças, incapazes de lutar por sua própria sobrevivência. Foi nesse contexto que os paulistas - não sem queixas dos jesuítas - resolveram tomar a questão do trabalho indígena nas próprias mãos. Em 1612, uma ata da Câmara de São Paulo representava contra os abusos de que se acusava os padres da Companhia, "que sendo as aldeias desta Capitania sempre suspeitas aos capitães e justiças desta dita vila, agora se introduzia pelo gentio um rumor dizendo que não conheciam senão os padres por seus superiores, e os ditos padres dizendo publicamente que as ditas aldeias eram suas, e que eram senhores no temporal e espiritual" (PRADO, 1972, p.33).

De fato, os jesuítas tinham boas razões para criticar os paulistas. Na realidade, os paulistas adquiriam a maioria dos índios por vias ilegais. Mas os colonos alegavam que os padres atrapalhavam o desenvolvimento de suas atividades econômicas. Como vimos, os paulistas contribuíram para o fim das tribos mais próximas a São Paulo, e. a partir de 1620 voltaram-se para as grandes expedições com objetivos na captura dos índios Guarani, no interior de uma América de complicados limites entre as terras de Portugal e Espanha. O vice-reino do Peru compreendia em suas fronteiras a província do Paraguai, uma das maiores da Companhia de Jesus, que abrangia todo um terri- tório hoje ocupado pela Argentina, Uruguai e Paraguai, além de outras terras que atualmente pertencem ao Brasil e à Bolívia. Não se deve confundir a província jesuítica do Paraguai com a Província do Paraguai e Rio da Prata, terra de Espanha e que tinha como capital Assunção. Em 1617, um decreto real dividiu esta província da Coroa em duas, a do Rio da Prata, que tinha como capital Buenos Aires, e a do Guairá, com capital em Assunção. Mas depois dos ataques paulistas às reduções jesuítas do Guairá entre 1629 e 1631, o nome Guairá foi substituído por Paraguai, sendo difícil evitar a confusão de nomes, expressiva também do conflito de poderes ali existente.

Os índios Guarani das reduções jesuítas teoricamente eram obedientes à Espanha, mesmo sem nunca terem sido conquistados pelos espanhóis, somente agrupados pelos jesuítas nas missões. Os jesuítas queriam organizar um estado teocrático dentro do Estado, cujas terras fossem cultivadas em comum, aceitando uma obediência à Coroa, mas contando com o apoio dos tribunais, dos governadores e bispos espanhóis, no que foram nesta região bem-sucedidos. Tinham o maior cuidado em manter os índios convertidos longe dos espanhóis e criollos, que não eram admitidos nas reduções, sendo que os governadores e bispos raramente os visitavam. Os limites da província jesuítica do Paraguai com o Brasil e com o vicereino do Peru estavam longe de ser definidos. E os moradores das regiões confinantes com as reduções olhavam esta vizinhança com desagrado; pois fosse qual fosse o limite de demarcação, a fronteira com a América portuguesa estava na capitania de São Vicente, de onde os paulistas atacavam há alguns anos as reduções dos índios Guarani. Os criollos, por sua vez, não defendiam as reduções dos ataques dos paulistas, pois preferiam vê-las destruídas para contar com os índios no trabalho de suas encomiendas (BOXER, 1973, p.83-85).

Nos terceiro e quarto decênios do século XVII os paulistas chegaram a ameaçar todas as reduções do 
Paraguai, fazendo valer seu espírito empreendedor. Nessa situação os jesuítas resolveram enviar procuradores a Roma e a Madri, pedindo providências protetoras. Os dois emissários conseguiram o que pediram na Europa em 1639, mais especificamente do papa Urbano VIII a publicação na América de uma antiga bula de Paulo III feita em 1537 a favor dos índios do Peru. A bula declarava que seriam excomungados os que cativassem, vendessem ou fizessem uso do serviço dos índios. Os jesuítas também obtiveram do rei de Espanha Filipe IV a ordem dada ao vice-rei do Peru para que fosse permitido aos índios das missões paraguaias armar-se contra os paulistas. A publicação no Rio de Janeiro de um breve com o conteúdo da bula de Paulo III em 1640 deu margem à muita confusão, com o convento dos jesuítas sendo arrombado pelos habitantes; mais violenta ainda foi a reação em Santos:

"Quando (...) o vigário leu, em voz alta, o breve do papa Urbano, a revolta foi imediata. Mal terminara o serviço quando se ergueu a multidão, aos gritos de 'fora com os padres da Companhia; mata os padres da Companhia, que são a causa de tudo isso' Os jesuítas entrincheiraram-se dentro de seu próprio convento, enquanto a multidão, do lado de fora, tentava arrombar-lhe as portas. Em uma de suas janelas apareceu então o superior (...) tendo nas mãos a píxide, à vista da qual a multidão ajoelhou-se com devoção, mas continuando a bradar, não sem incongruência, 'fora com os padres; matem os padres'. Foi debalde que o padre Carvalhais tentou apaziguá-la, perguntando aos amotinados se queriam desobedecer ao Papa, repreendendo-os por estarem se comportando pior do que se fossem ingleses hereges" (BOXER, 1973, p.148-149).

Não se sabe ao certo a data em que o breve foi publicado em São Paulo, mas ele não foi tornado público pelos jesuítas do lugar, que aguardaram a chegada das ordens complementares do rei para só então divulgá-lo. Houve revolta após a sua publicação, acompanhada de ameaças contra os jesuítas, contudo, nem os padres nem o seu colégio foram molestados. Mas a reação não se fez esperar. Os concelhos de São Paulo e Rio de Janeiro reuniram-se nesta última cidade para discutir como fazer frente ao breve. Ficou resolvido expulsar os jesuítas da capitania de São Vicente, pois os jesuítas seriam os principais responsáveis pelo breve, já que as outras ordens religiosas nunca se preocuparam com a questão da liberdade dos índios. A decisão teria sido facilitada - ou assim quiseram fazer crer os jesuítas - pelos habitantes do Rio. Eles teriam escrito aos paulistas afirmando que se eles expulsassem os jesuítas, os habitantes do Rio seguiriam o seu exemplo. Falou-se também que se os padres fossem expulsos de São Vicente todos iriam fazer pressão junto ao Papa, para que se cancelasse o breve ${ }^{9}$.

Procedeu-se assim, à expulsão em São Paulo; durante o ano de 1640, a vila de Piratininga teria vivido em alvoroço, tomando medidas extremas para realizar "a botada dos padres fora". Reunida em 2 de julho, a Câmara intimou os padres a "que dentro em seis dias despejassem esta vila e se recolhessem ao Colégio do Rio de Janeiro para segurança de suas vidas, honras e fazendas" As propriedades dos jesuítas foram confiscadas, e a administração dos aldeamentos foi transferida para o poder público. Quando souberam que os habitantes de Santos se mostravam hesitantes quanto à expulsão, os paulistas armaram bandos que desceram a Serra para fazer uma demonstração de força, pressionando a saída de todos os jesuítas, que partiram de Santos em 3 de agosto (PRADO, 1972, p. 33, e BOXER, 1973, p. 150).

No Rio de Janeiro, com o auxílio do governador Salvador Correia, os jesuítas já tinham proposto em

\footnotetext{
${ }^{9} \mathrm{O}$ documento básico utilizado pelos historiadores é a Relação da Aclamação que se fez na capitania do Rio de Janeiro do Estado do Brasil, \& nas mais do sul, ao senhor rei Dom João o IV por verdadeiro rei, \& senhor do seu reino de Portugal, com a felicíssima restituição que dele se fez a Sua Majestade que Deus guarde, Lisboa, Oficina de Jorge Rodrigues, 1641, Biblioteca Nacional - Rio de Janeiro, códice 26-3-25-2.
} 
22 de junho do mesmo ano uma conciliação em que cada lado cedesse parte de suas pretensões: os padres declararam desistir dos direitos que pudessem ter com a publicação e execução da bula, que não se envolveriam na administração dos índios que os moradores tivessem em suas casas, mas só nas aldeias, e prometeram esquecimento do ataque feito ao colégio. A Câmara e o povo comprometeram-se a desistir, e a retirar os capítulos e resposta que tinham, sem disso tornar a tratar, salvo se os padres faltassem ao que capitulavam. Os habitantes da vila de São Vicente, também por intervenção de Salvador Correia, fizeram pouco depois como os do Rio de Janeiro (VARNHAGEN, 1981, p.132).

Mas em São Paulo, a despeito dos esforços do governador, que teria chegado a ir a Santos, os paulistas enfrentaram as suas ameaças, fazendo bloqueios nos caminhos impedindo sua chegada ao planalto. Segundo Paulo Prado, "era a revolta declarada contra a autoridade do Reino." Varnhagen afirma que a Câmara de São Paulo resolveu expulsar os jesuítas em julho de 1640, depois concordou em tolerá-los sob condições, mas em 19 de maio de 1641 votou que a expulsão fosse levada a efeito (PRADO, 1972, p.34, \& VARNHAGEN, 1981, p.132). Os paulistas então elaboraram um longo memorial enviado por seus procuradores à corte portuguesa em 1642, relativo à liberdade dos índios.

Neste texto, os paulistas queixavam-se da "amizade muito especial do governador Salvador Correia pelos reverendos padres, aos quais havia solenemente prometido fazer com que se instalassem de novo nestas capitanias, fosse como fosse". Que os jesuítas buscavam "tirar, privar e esbulhar aos ditos moradores da posse imemorial, e antiquíssima, em que estão desde a fundação deste Estado até o presente." Os paulistas protestavam contra os amplos poderes dos quais se achava investido Salvador Correia, e que ele, o governador, se aproveitava deles para garantir a volta dos jesuítas. Finalizavam pedindo que o administrador em questão fosse substituído, prometendo a descoberta de "outro Peru" dentro dos limites da América portuguesa, caso fosse nomeado um sucessor de maior valia (apud VARNHAGEN, 1981, p.133-136, BOXER, 1973, p.166, \& MONTEIRO, 1995, p.146).

Os jesuítas foram readmitidos em São Paulo somente treze anos depois, cedendo à pretensão de envolvimento na questão da escravidão dos índios. Contudo, do que foi exposto podemos inferir que existia ainda um outro ponto de conflito envolvendo as relações dos paulistas com as autoridades governamentais na América portuguesa, e que as circunstâncias mencionadas até aqui foram entremeadas pelos acontecimentos referentes à restauração da independência portuguesa em dezembro de 1640 .

\section{Os paulistas e o governador}

Em carta de janeiro de 1606 dirigida ao donatário da capitania de São Vicente, os juízes e vereadores da vila de São Paulo já expunham as suas insatisfações com o desempenho das autoridades: “... porque assim os capitães e ouvidores que Vma. manda, como os que cada quinze dias nos metem os governadores gerais em outra coisa não entendem nem estudam senão como nos hão de esfolar, destruir e afrontar, e nisto gastam o seu tempo, eles não vêm nos governar e reger, nem aumentar a terra que o Sr. Martim Afonso de Souza ganhou e S. M. lhe deu com tão avantajadas mercês e favores. Vai isto em tal maneira e razão, que pelo eclesiástico e pelo secular não há outra coisa senão pedir e apanhar (...). E se falamos prendem-nos e excomungam-nos, e fazem de nós o que querem, que como somos pobres e temos o remédio tão longe não há outro recurso senão abaixar a cerviz e sofrer o mal que nos põem ..." (apud PRADO, 1972, p. 31-32).

Os representantes de São Paulo manifestaram no texto acima o seu descontentamento para com a confusão de poderes na administração da América portuguesa, expressos tanto entre a burocracia da Coroa e os privilégios dos donatários, por um lado, quanto, 
por outro, entre a autoridade régia e a autonomia municipal. Foi sempre por meio da Câmara de sua vila que os paulistas conseguiram expressar seus interesses, não raro explorando esses conflitos com habilidade para conseguir o que queriam. Contudo, havia uma questão subjacente a tudo, e que levava a outro conflito de poderes: a escravidão indígena. Certamente mais interessada no desenvolvimento da produção americana do que na liberdade dos índios, a Coroa consentiu em termos velados com a existência da escravidão indígena em São Paulo, resultante das guerras justas. As ordens promulgadas pela Coroa garantindo a liberdade dos nativos eram inúteis, como a carta régia de D. Sebastião de 20 de março de 1570 influenciada pelas idéias jesuíticas de proteção ao índio, a lei de 11 de novembro de 1595 de Filipe II proibindo a escravização do gentio do Brasil, e o alvará de 26 de julho de 1596, sobre o mesmo assunto (HOLANDA, 1985, p. 284).

Essa postura inconstante das autoridades aparece com nitidez no caso narrado por John Monteiro: "Em 1609 por exemplo, após a publicação de uma lei declarando a liberdade incondicional de todos os índios, Hilária Luís enviou uma petição ao governador perguntando-lhe se os índios trazidos por seu recém falecido marido podiam entrar nas partilhas. $\mathrm{O}$ parecer do governador foi curto e direto: os índios não podiam entrar em inventários por serem livres pelas leis do Reino. Instado igualmente a se pronunciar, o juiz dos órfãos de São Paulo, no entanto, afirmou que 'é uso e costume darem partilhas de peças forras aos órfãos para seu sustento e serviço e não para se venderem'. Inconformado com a resposta, o governador pediu o parecer do procurador dos índios e de um ouvidor, ambos, cabe frisar, donos de cativos índios. O primeiro reafirmou que o caso se enquadrava no 'uso e costume da terra' e o segundo acrescentou que, sem a herança, os órfãos quedarán miserables pidiendo limosna. No final do processo, o governador acabou por recuar, autorizando a inclusão dos índios no inventário" (MONTEIRO, 1995, p.140).
Desse modo, muitas vezes o "uso e costume da terra" acabava prevalecendo nas relações entre os paulistas e o poder temporal, apesar dos esforços da Coroa em proporcionar aos jesuítas exclusividade sobre o acesso ao trabalho indígena. Neste sentido, a formação da sociedade paulista no século XVII não parece tão distante da sociedade constituída na região açucareira. No planalto, os índios formaram sempre a base de toda a produção efetuada, tanto quanto os africanos em Pernambuco ou Bahia. Sem os índios, os portugueses de São Paulo não conseguiriam manter nem suas mulheres e filhos, tal o desprezo que sentiam pelo trabalho manual.

Também os conflitos entre famílias eram marca da sociedade paulistana da época. Em 1641, Fernando de Camargo matava com um só golpe de adaga a Pedro Taques de Almeida, junto às portas da igreja matriz da cidade. Era esse o resultado de um conflito travado um ano antes naquele mesmo Largo da Sé, em que os grupos inimigos pertencentes a duas das famílias mais importantes da vila realizaram uma batalha aberta, com muitas mortes e ferimentos, revelando a fragilidade de um poder institucionalizado naquele núcleo urbano (PRADO, 1972, p.55).

Mas por volta de 1640, não eram somente esses os problemas apontados pelos paulistas. Como já foi mencionado, existia na capitania de São Vicente uma insatisfação generalizada com o governador do Rio de Janeiro, Salvador Correia de Sá e Benevides (16021686), que possuía jurisdição também sobre as capitanias do sul. Segundo Charles Boxer, Salvador Correia de Sá fez sua primeira visita ao Brasil na adolescência; foi educado por jesuítas, em cuja Companhia uma vez mostrou interesse em entrar. Sua família paterna manteve ligações estreitas com os jesuítas no Brasil, desde que Mem de Sá se revelara amigo destes na época da fundação do Rio de Janeiro, em meados do século XVI. Até então, a família dos Sá constituiu uma verdadeira oligarquia no governo desta cidade e de sua capitania, para o qual 
Salvador Correia foi nomeado de 1637 a 1643 (BOXER, 1973, p.132-166).

Para os países ibéricos e seus impérios ultramarinos, aqueles eram tempos difíceis. Em guerra com a Espanha, os holandeses já tinham invadido a Bahia, e a partir de 1630 apoderaram-se da capitania de Pernambuco, que receberia em 1637 o conde João Maurício de Nassau, animando a empresa batava na América. Em função do conflito instaurado no litoral norte, era tarefa de Salvador Correia prover de gêneros alimentícios as zonas afetadas, e recrutar mais soldados nas capitanias de baixo para o confronto inevitável. Mas houve imensas dificuldades nesse recrutamento. Os paulistas utilizavam os menores pretextos para não cumprir as determinações régias. Salvador deu ordem expressa para que ninguém saísse de São Paulo em busca de índios durante o conflito com os flamengos, ordem burlada pelos paulistas. As tensões entre Salvador Correia e os paulistas agravaram-se com a expulsão dos jesuítas de São Paulo em 1640. O apoio que Salvador Correia dava aos jesuítas lhe valera muitos inimigos, além dos que detestavam o poderio dos Sá no Rio de Janeiro. De fato, Salvador Correia já era um homem abastado nesta época, pelo patrimônio de sua família e pelo casamento com uma rica herdeira espanhola. Possuía por volta de setecentos escravos em suas terras com plantações de cana-de-açúcar e criação, sendo possivelmente o maior proprietário da América portuguesa e, juntamente com o vice-rei D. Jorge de Mascarenhas, marquês de Montalvão na Bahia, uma das duas personagens mais importantes naquele cenário político e social ${ }^{10}$.

10 "Superintendente em todas as matérias de guerra na Repartição do Sul”, este era o título primitivo de Salvador Correia de Sá e Benevides. Em 1639 e em 1641 seus poderes foram aumentados pelo marquês de Montalvão. Ibidem, p. 157. Varnhagen confirma que os poderes concedidos a Salvador Correia foram dados pelo vice-rei Montalvão, quando ordenava se efetuar no Rio a aclama-
Em janeiro de 1641, uma embarcação partia de Lisboa para o Brasil a fim de levar a notícia da Restauração vitoriosa em Portugal, chegando em 15 de fevereiro à Bahia e entregando os despachos ao vice-rei. Sobre esse fato, as fontes portuguesas informam que Montalvão aceitou o acontecido em Lisboa, tomando todas as providências necessárias. Contudo, em função de suspeita de envolvimento espanhol, Montalvão seria depois afastado do cargo e substituído por uma junta governativa, que o acusaria de tentar levantar a guarnição em favor do rei de Espanha. $\mathrm{Na}$ Corte, o ex-governador-geral seria detido para averiguações e morreria na prisão, apesar de não ser considerado culpado por D. João IV.

Tendo conseguido na Bahia proclamar D. João IV rei, Montalvão preocupou-se em assegurar que Salvador Correia de Sá e as capitanias do sul fizessem o mesmo. Intensa correspondência foi então remetida ao governador e outras pessoas influentes no Rio, reforçando a necessidade de se acompanhar o ocorrido em Portugal e seguido pela Bahia. O portador dessas cartas foi um jesuíta, mais uma vez revelando a influência da Companhia. O emissário chegou ao Rio em 10 de março de 1641, entregando secretamente a Salvador os despachos de Montalvão. Mais uma vez, alguns relatos afirmam que houve hesitação por parte do governador, e que teriam sido as ameaças dos jesuítas que afastaram suas dúvidas, conduzindo-o a tomar o partido de D. João IV. De qualquer modo é estranha a sua desculpa sobre a demora em posicionar-se, "de que a alegria provocada pela inesperada notícia o tivesse feito esquecer-se momentaneamente de si próprio." As suspeitas sobre Salvador Correia

ção de D. João IV, julgando prudente para assegurá-la satisfazer as ambições do dito governador, concedendo-lhe portanto poderes de capitão-general, com o título de almirante e governador. A Coroa forneceu ainda a Salvador as mesmas regalias que antes tivera D. Francisco de Sousa (VARNHAGEN, 1981, p.137). 
possuíam algum fundamento, pois seu casamento com uma criolla espanhola herdeira de considerável fortuna tornara-o um grande latifundiário, com influência também no império espanhol americano.

No entanto, as ações posteriores do governador são indicativas do fim de sua suposta indecisão. Diante da guarnição formada, convocou os notáveis para uma reunião no colégio dos jesuítas, chamando à parte cada pessoa que chegava, percebendo-lhe as reações, colhendo suas opiniões, e só assim abrindo a reunião: "Relembrou então que D. João havia sido aclamado em todo Portugal sem qualquer oposição, e que aquele exemplo fora seguido na Bahia (...) Aludiu à natureza milagrosa da Restauração da monarquia legítima, do que era prova a ausência de derramamento de sangue e os muitos sinais e prodígios relatados em cartas particulares que ele tinha recebido de amigos (...) Depois que a declaração de fidelidade foi registrada na devida forma e por todos os presentes assinada, Salvador levantou-se, por sua vez, da cadeira e bradou - 'Salve D. João IV de Portugal!', exclamação repetida entusiasticamente por toda assembléia" (VARNHAGEN, 1981, p.160). A cidade teria vivido em festejos por dois dias seguidos, tendo ordenado Salvador a todas as pessoas de maiores posses que prestassem a sua contribuição a esses eventos, sob pena de serem consideradas descontentes.

Assim, história da aclamação em São Paulo junta-se ao episódio da expulsão dos jesuítas, e ao contraponto fornecido pelas animosidades em relação ao governador do Rio de Janeiro. Diante das ameaças de Salvador Correia em invadir São Paulo, os habitantes da cidade sabiam das poucas chances que o governador possuía para fazer uso da força armada. Apesar de ter no Rio de Janeiro uma forte guarnição, não era conveniente para Salvador naquele momento retirar um deslocamento daquele local, devido ao perigo de um ataque holandês. Além disso, São Paulo era protegida pela Serra do Mar, e portanto praticamente invulnerável a qualquer ataque externo, diferente de
Santos, onde Salvador Correia instalou de novo os jesuítas tão logo encontrou oportunidade. No entanto, em 1648 o mesmo Salvador, já general das frotas do Brasil, retiraria essa forte guarnição do Rio de Janeiro, sob a mesma ameaça holandesa, para reconquistar Angola para Portugal, o que indica vários aspectos a serem observados: os interesses diferenciados no conjunto do Império de acordo com as suas diferentes regiões, a importância de Angola como centro fornecedor de mão-de-obra escrava para a América portuguesa, a prevalência desta região africana sobre São Paulo, que permanecia ligada ao tráfico ameríndio, além das ligações comerciais entre o Rio de Janeiro e Luanda.

Como São Paulo permaneceu resistente, Salvador Correia resolveu ir até o planalto pessoalmente. Os paulistas bloquearam o caminho, argumentando que a real intenção do governador era ir ao Paraguai com a mulher, após incentivar uma rebelião indígena em São Paulo e devastar a região. Os paulistas também alegaram que a autoridade maior de Salvador Correa sobre as capitanias do sul fora obtida por manobras ilícitas, insistindo os vereadores de São Paulo para com os seus colegas de Santos que o prendessem, apontando-o como um desertor em potencial em favor dos espanhóis. Frustrado em seu projeto, Salvador Correia recebeu ordens do vice-rei para retornar ao Rio de Janeiro, pois a Coroa tinha voltado atrás no referente a sua ampla jurisdição sobre as capitanias do sul. Não havia restado outra alternativa ao governador: um acordo, firmando com os paulistas um compromisso pelo qual estes, embora se recusassem a readmitir os jesuítas e a dar liberdade aos cativos índios, concordavam em ser supervisionados no trabalho das minas e na arrecadação dos quintos reais. Comprometeram-se também a obedecer o governo legal, e a abrir os caminhos em direção ao mar.

Por esse e outros episódios, por sua localização geográfica e pela fama de seus habitantes, a cidade de São Paulo durante o século XVII ganhou o epíteto de 
a Rochela do Brasil, ou a Rochela do sul, numa alusão à cidade francesa de La Rochelle. Localizada no sudoeste da França, de maioria calvinista, essa cidade, na segunda metade do século XVI, por causa da resistência de seus habitantes empedernidos, deu muito trabalho às tropas reais dos Valois-Angoulême durante as guerras religiosas. A cidade protestante ficou conhecida pelo cerco de La Rochelle em 1573, quando, após o massacre da noite de São Bartolomeu, no reinado de Carlos IX, as tropas reais comandadas pelo duque d'Anjou não conseguiram entrar na cidade, que passou a ter sua liberdade religiosa tolerada, somente submetida à monarquia católica no reinado de Luís XIII em 1628, em pleno processo de afirmação do Estado absolutista francês (LADURIE, 1994). O sentido religioso e ao mesmo tempo político da insubordinação reforça essa analogia, desenvolvida nos escritos de autores franceses do século XVIII identificados com a causa jesuíta. Misturando muitas informações errôneas, esses diziam que os habitantes de São Paulo viviam em sistema de república, que eram todos de origem mameluca, ou que a cidade estava situada sobre uma grande montanha rochosa, que a tornava inexpugnável (CHARLEVOIX, 1757, p.159 e p.401-402 e D. VAISSETTE, apud MADRE DE DEUS, 1975) ${ }^{11}$.

Mas não era apenas São Paulo durante o século XVII que tinha fama de terra de vassalos rebeldes.

${ }^{11}$ Os epítetos a rochela do Brasil, ou do Sul, são citados por Charles Boxer, e John Monteiro. Sérgio Buarque de Holanda faz referência às "últimas rochelas" para tratar da extinção do quilombo dos Palmares no fim do século XVII, e Beatriz Catão Cruz Santos intitula "A rochela de Portugal" um capítulo de seu livro, com base numa carta do padre Antônio Vieira sobre o Maranhão no século XVII. A idéia do Maranhão como "rochela" parece bastante significativa, pois lá também, como em São Paulo, ocorreram conflitos envolvendo jesuítas e colonos pela escravidão de indígenas (BOXER, 1973, p. 45, MONTEIRO, 1995, p. 216, HOLANDA, 1985, v.2, p. 24-26, e SANTOS, 1997, p. 45-72).
Também no Rio de Janeiro e no Maranhão havia revoltas de colonos. A breve consideração desses movimentos, em suas semelhanças e diferenças com o ocorrido em São Paulo por volta de 1640, abriria caminho para uma explicação sobre os papéis específicos das conquistas ultramarinas e da América portuguesa no conjunto do império português.

\section{Os paulistas e o império}

Em janeiro de 1660 explodia no Rio de Janeiro uma revolta contra o controle dos Sá na capitania. Os motivos, ao que parece, eram sobretudo anti-fiscais. Diante do atraso no pagamento das guarnições locais, o governador Salvador Correia de Sá lançava novos impostos, pressionando para esse fim a Câmara da cidade, retirando-se em seguida para as fronteiras do sul. Em São Gonçalo, os habitantes se sublevaram, apresentando um ultimato ao governador interino. Os revoltosos juravam lealdade ao rei de Portugal D. Afonso VI, mas acusavam Salvador Correia de Sá de ser "tirano", pleiteando assim a supressão dos impostos lançados, que se reduzisse também o número de oficiais e de eclesiásticos, e novas eleições para a Câmara, a fim de se eleger representantes isentos da pressão do governador. Os revoltosos conclamavam a população para um encontro em frente à Câmara, recebendo a adesão dos soldados, enquanto o governador interino se refugiava no mosteiro de São Bento. A multidão saqueava as casas das autoridades, e eram declarados vagos os cargos ocupados por todos os membros da família Sá, sendo aclamado um novo governador da capitania, Agostinho Barbalho. De São Vicente, quando voltava do sul, Salvador Correia mandava carta para o Rio, confirmando o governante escolhido, abolindo os impostos e concedendo perdão ao movimento, excetuando-se os líderes. Mas os rebeldes depuseram Barbalho, colocando em seu lugar uma junta rebelde. Retomavam então as acusações contra Salvador Correia, acrescentando outras mais 
graves, como a de conspirar em favor do espanhol D. João de Áustria para que este assumisse o trono português, casando com D. Catarina de Bragança, irmã mais velha de D. Afonso VI. Mas em fevereiro de 1661, com o apoio da esquadra que chegava do Reino, Salvador Correia tomava o Rio de Janeiro, os revoltosos se refugiando nos conventos. Organizava então uma sumária corte marcial, que condenava à morte Jerônimo Barbalho. Sua cabeça foi exposta em praça pública. Os outros líderes foram enviados para a Relação da Bahia. Os novos vereadores foram substituídos pelos anteriores. No entanto, essas decisões intempestivas não teriam sido bem aceitas na Corte: Salvador Correia foi removido do cargo de governador do Rio de Janeiro. Além disso, o Conselho Ultramarino/ órgão do qual, aliás, Salvador Correia iria fazer parte manifestava a sua preocupação de que os habitantes da cidade não pensassem ter feito algo ruim, já que poderiam se sujeitar a algum outro país que não Portugal. Pois a revolta no Rio de Janeiro tinha sido muito expressiva, por compreender entre seus participantes proprietários fluminenses, membros do clero, com o apoio dos homens livres e pobres das cercanias. Doravante, a cidade do Rio de Janeiro iria cada vez mais afirmar-se como de importância capital para a coroa portuguesa, como centro comercial e político no Atlântico sul (SOUZA, 1995, p.11-15).

Ao comparar os fatos de São Paulo por volta de 1640 e os ocorridos no Rio de Janeiro em 1660-1661, percebemos que ambos os movimentos manifestavam um apego à escolha de indivíduos mais afinados com os interesses locais, em contraposição aos governantes nomeados pela Coroa, nos dois casos, a mesma pessoa: Salvador Correia de Sá e Benevides. Mas o antagonismo em relação a oligarquia dos Sá no Rio pode nos fornecer mais pistas. Por ele percebemos acusações de parcialidade por parte do governador em relação à causa de Espanha, numa época em que a independência portuguesa não se encontrava assegurada. Os fluminenses colocavam-se contra esta tendên- cia, optando pela soberania portuguesa - mesmo que isto tenha sido manifestado aqui somente ao nível da retórica. Esse envolvimento de Salvador Correia com o império espanhol, salientado no Rio de Janeiro, já foi mencionado no contexto paulista ${ }^{12}$. No entanto, em São Paulo esses argumentos não constituíam o cerne das acusações dirigidas ao governador, mais caracterizadas pela suposta proteção fornecida aos jesuítas. Em contrapartida, no Rio de Janeiro a questão do cativeiro indígena não era explicitada como foi em São Paulo por volta de 1640, ou como seria posteriormente no Maranhão em 1684. Tais observações podem ser indicativas para a percepção de posturas diferenciadas entre paulistas e fluminenses referentes ao poder central, que por sua vez traduziam posições diversas das duas capitanias no conjunto do império português.

\footnotetext{
${ }^{12}$ Salvador Correia tinha ascendentes como Estácio de Sá e o avô paterno Salvador Correia de Sá, governadores do Rio de Janeiro. Ambos eram sobrinhos do governador-geral Mem de Sá. Martim de Sá, pai de Salvador Correia, foi governador do Rio de 1606 a 1608 , de 1618 a 1620 , e de 1623 a 1632, quando este último recebeu o comando das tropas na margem oeste do rio Paraguai. Mestre de campo general das forças espanholas do Alto Paraguai, ali lidou com as tribos indígenas. Em 1635, ele esposou Catalina de Ugarte y Velasco, viúva de um rico proprietário espanhol no Prata, sobrinha do vice-rei do Peru. Primos maternos espanhóis de Salvador Correia também assumiam cargos destacados em Buenos Aires. Somando os prêmios das guerras com as propriedades de sua mulher, ele juntou vastos bens na região platina. A partir de 1637 no governo do Rio, dirigiu as capitanias de baixo até 1643, ocupando este mesmo posto em 1648, e entre 1658 e 1661. Seu tio-avô Duarte Correia Vasqueannes exerceu o governo do Rio de 1644 a 1647, e de 1648 a 1650. Partiu dele a ajuda para a frota de Angola, reconquistada e governada por Salvador Correia entre 1648 e 1652. Seu filho João Correia de Sá foi mestre de campo do Rio de Janeiro em 1659 e governador da capitania em 1661. Salvador Correia foi também membro do Conselho Ultramarino a partir de 1661 e do Conselho de Guerra desde 1652 (BOXER, 1973).
} 
Enquanto São Paulo denotava uma posição mais autônoma, marcada pela defesa da caça ao índio no sertão, o Rio, capitania real desde a fundação da cidade em 1565, afirmava sua integração nos negócios atlânticos, que envolviam consistentes ligações com Luanda, e com o porto de Buenos-Aires, porta de entrada da região platina pela via do contrabando. Vínculos que envolviam sobretudo o tráfico negreiro. A capitania do Rio de Janeiro vivia assim nesse processo uma sujeição crescente aos interesses comerciais do império luso, pautados pelo incentivo ao comércio de africanos escravizados obtidos principalmente em Angola. Neste percurso era natural que a capitania do Rio de Janeiro se despojasse em termos de controle político de certa oligarquia local, para ser cada vez mais submetida ao poder régio. A poderosa família Sá era também interessada nessas transações comerciais triangulares entre Rio, Luanda e Buenos Aires, como ficaria evidente na participação de Salvador Correia na reconquista e no governo de Angola entre 1648 e 1651, bem como em suas tentativas de usufruir do comércio da prata peruana. A complexa personagem em questão era figura comprometida por laços de parentesco, negócios e terras com a união ibérica, tendo correspondido aos ímpetos centralistas do conde-duque de Olivares, contribuindo também para a união dos impérios espanhol e português. A permanência da oligarquia dos Sá no Rio de Janeiro esfacelava a autoridade régia na América portuguesa, fato comprovado quando, na Bahia, o governador-geral Francisco Barreto não ajudou Salvador Correia na repressão da revolta no Rio em 1660. Podemos, contudo, cogitar que a permanência de personagem outrora tão ligada ao império espanhol - bem como poderosa na composição de uma oligarquia no Rio de Janeiro - nos quadros da administração ultramarina portuguesa, era sinal de sua cooptação ao poder régio lusitano. Por outro lado, esta mesma permanência também podia ser indicadora de que este poder régio, nos reinados de D. João IV e D. Afonso VI, não era tão forte assim.
Desse modo adentramos num outro campo explicativo, percebendo as diferenças entre São Paulo e Rio de Janeiro durante o século XVII. A rebeldia dos vassalos de São Paulo, muito relacionada à defesa do aprisionamento e do tráfico de ameríndios, parecia não justificar-se apenas pela rejeição de determinações eclesiásticas de ordem moral, bem como por conflitos circunstanciais com autoridades da Coroa que respaldavam esta tendência. Por trás dessas contendas existia algo que dizia respeito ao enquadramento da capitania de São Vicente, especialmente do planalto paulista, numa ordem maior referente ao império ultramarino português. Sobre este aspecto, Luiz Felipe de Alencastro oferece uma abordagem diversa - mas não divergente - de John Monteiro. Enquanto este último dirige suas atenções para o próprio continente americano, numa abordagem da vida social em Piratininga, Alencastro trabalha com a dinâmica das relações ultramarinas no conjunto do Atlântico, considerando a participação de outras conquistas lusitanas, não somente na América, mas principalmente na África (ALENCASTRO, 1994). Este historiador defende que a introdução de africanos na América, acompanhada do embargo ao cativeiro indígena, permitia a Portugal comandar de forma mais firme a produção ultramarina americana, pois os colonos deviam recorrer ao comércio mercantil para exportar seus produtos, mas também para importar seus fatores de produção. Esse fenômeno marcaria a colonização portuguesa no espaço do Atlântico. Realizando a reprodução da produção colonial, o tráfico negreiro era um instrumento central no império português do Ocidente. Essa atividade transcendia o quadro econômico e adquiria contornos políticos. Desse modo, a prática do poder imperial nos territórios ultramarinos e as trocas entre o Reino e as províncias ultramarinas americanas e africanas ocorriam no âmbito do tráfico negreiro. O conflito entre a produção mercantil dos colonos e a "evangelização" dos ameríndios seria assim atenuado pelo tráfico negrei- 
ro. Membros do clero regular, sobretudo jesuítas no caso português, propunham aos governos ibéricos a introdução do tráfico transatlântico, para que o cativeiro africano libertasse os ameríndios do jugo imposto pelos colonos. Isso gerava contendas nas áreas não penetradas pelo escravismo, onde predominava o trabalho compulsório indígena. A acumulação proporcionada pelos escravos índios era possível, mas não compatível com o sistema colonial, esbarrando na circulação do capital mercantil, na rede fiscal da Coroa, na questão da evangelização e, portanto, nos interesses políticos do Reino. Esse conjunto de fatores não permitia que se firmasse em torno do comércio de índios um sistema semelhante ao trato negreiro.

Após a fundação da Companhia das Índias Ocidentais em 1621, os ataques holandeses à Bahia entre 1624 e 1625 e a tomada de Olinda e Recife em 1630 foram acompanhados de investidas contra o Espírito Santo, a Paraíba e, do outro lado do mar, contra Mina, Benguela, Luanda, Fernando Pó, São Tomé e Cabo Verde (ALENCASTRO, 1994, p. 5960). Tal conjuntura teria gerado uma diminuição do trato negreiro para a América portuguesa. Naus da carreira do Brasil eram capturadas, perdendo milhares de caixas de açúcar, pau-brasil, tabaco, escravos e outras mercadorias. Os embaraços do trato negreiro diante do poderio naval holandês aumentavam o tráfico de ameríndios neste lado do Atlântico. $\mathrm{Na}$ época, se armava em São Paulo a expedição de Raposo Tavares, envolvida na preação indígena, a Câmara da vila apoiando a empreitada. Quase todos os homens válidos da vila, entre eles parentes próximos do ouvidor da capitania, Amador Bueno, se juntaram à grande bandeira, que de julho de 1628 a meados de 1630 capturaria entre quarenta e sessenta mil índios Guarani das reduções do Guairá. Manuel Preto atacaria de novo o Guairá em 1629. Outras investidas por parte de Cristóvão Diniz devastariam a província em 1631. Aterrorizados, jesuítas e Guarani fugiam da área. Em busca de mais presas, os paulistas atacaram a partir de 1635 reduções e aldeias no Tapes, dizimando-as em apenas seis anos.

Estava feito o nexo entre a quebra do fluxo negreiro, o aumento do preço dos escravos e a demanda de gentio, embora não do modo apregoado pela historiografia tradicional paulista, como já foi questionado por John Monteiro. Sem constituírem uma resposta direta à queda das entradas de africanos nos engenhos do nordeste, as bandeiras do Guairá-Tapes se apresentavam, também, como um reflexo na América portuguesa do declínio conjuntural das trocas atlânticas, já que a busca de mais braços indígenas pelos paulistas era relacionada ao aumento de produtividade na capitania de São Vicente, cujos gêneros iam suprir a carência de produtos vindos do Reino. Por sua vez, o crescimento do tráfico de ameríndios no planalto paulista, simultaneamente centro de preadores, produtores escravistas e mesmo exportadores de mão-de-obra, provocava graves incidentes no sul. Num primeiro momento, uma cumplicidade nos negócios fazia aproximar os "lusobrasileiros" dos "hispano-americanos". De um lado, os senhores de engenho do Rio e fazendeiros e preadores de São Paulo; do outro, espanhóis rebeldes de Tucumã e Paraguai, vizinhos dos maiores aldeamentos de indígenas da América do Sul. Já vimos como, através do exemplo fornecido pela vida de Salvador Correia de Sá, os impérios português e espanhol na América tinham se aproximado no reinado de Filipe IV, antes da restauração da independência lusitana.

Mas, em face do bloqueio naval da Companhia das Índias Ocidentais no litoral norte da América portuguesa, surgia uma nova força comercial no Atlântico. Desviadas para o sul, as rotas subequatoriais passaram a puxar o Rio de Janeiro para as trocas marítimas: a prata peruana e os escravos angolanos se inseriam nas carreiras fluminenses, formando o triângulo Rio - Luanda - Buenos Aires. Destarte, ainda ativas na segunda e terceira décadas do século XVII, as expedições fluminenses de caça ao índio eram colocadas de lado em função das transações dos 
jesuítas, dos Sá e das famílias que lhes eram agregadas no comércio do Atlântico: construção naval, negócios do tráfico negreiro, trocas com o Prata. Essa reviravolta levava o comércio atlântico dos fluminenses a se separar das investidas continentais, indígenas, autárquicas e antijesuíticas dos paulistas. A "guinada atlântica" do Rio de Janeiro teria importantes conseqüências políticas, definindo para São Paulo e seu planalto uma autonomia baseada no cativeiro indígena, que se distinguia da prática comum no conjunto do Império. Somente assim podemos explicar o envolvimento posterior de personalidades ligadas ao Rio de Janeiro na reconquista de Angola, em 1648 (ALENCASTRO, 1994, p. 82-102).

Entretanto, o vínculo dos paulistas com a região do Prata era pautado pelas trocas terrestres e pelo tráfico de indígenas destinados à produção regional. Durante o terceiro e o quarto decênios do século XVII, espanhóis reinóis e famílias hispânicas do Paraguai dirigiam-se para Piratininga, aos poucos se unindo a famílias vicentinas de tradição. Ligados aos colonos do Prata por laços de parentesco e de negócios, os paulistas passaram também a contar com bandos rebeldes espanhóis nos assaltos às reduções ${ }^{13}$.

A manobra precipitada dos jesuítas, colocando em prática o breve papal contra o cativeiro ameríndio, desencadearia os já comentados motins no Rio de Janeiro e na capitania de São Vicente. Chegavam as novas da Restauração, estopim da aclamação do rei paulista em abril de 1641. A este respeito Felipe de Alencastro busca identificar em sua argumentação alguns pontos de contato entre as narrativas provavel-

\footnotetext{
${ }^{13}$ Sobre a imigração de espanhóis do Paraguai para São Paulo, eventualmente implicados no movimento de abril de 1641, Pedro Taques informa - como observado por Alencastro - sobre a desconfiança que estas famílias imigrantes eram perseguidas por crime de lesa-majestade em Madri. (LEME, 1980, p.269) Felipe de Alencastro suspeita de que essas poderiam ser famílias cristãsnovas acusadas pela inquisição, após a ofensiva paulista sobre o
}

mente inventadas dos memorialistas Frei Gaspar e Pedro Taques, e os estudos empreendidos sobre o planalto paulista, como a imigração de espanhóis rebeldes e a posição autônoma de São Paulo em contraposição ao Rio. Mas exagera a "mistificação" do episódio, embalado pela crítica consistente que faz ao ufanismo dos historiadores tradicionais paulistas. $\mathrm{O}$ historiador confundiria um pouco assim o texto sobre o evento - o relato de Frei Gaspar - com o sentido e probabilidade histórica do acontecimento, preferindo classificá-lo como "legendário" em vez de concebê-lo como historicamente possível. As considerações do autor, aludindo ao documento de 1700 que elogiava a família paulista na época da descoberta do ouro como sendo de interesse do governador do Rio são plausíveis. Mas elas não excluem o argumento aqui exposto (ALENCASTRO, 1994, p.97-98).

Diante das limitações da pesquisa aqui realizada, que não cotejou fontes originais sobre o tema, importa no entanto perceber que aquele evento, não obstante a deturpação historiográfica de seu enredo, fazia completo sentido naquele contexto, não pela lealdade do aclamado - como quiseram fazer crer as memórias e histórias paulistas -, mas pela rebeldia dos vassalos. Mais do que a fidelidade de Amador Bueno, deveria saltar aos olhos da Coroa a autonomia dos paulistas. Faz falta, nos estudos que mencionaram o episódio, a consideração de que por esta época o poder monárquico português era de fato muito fraco, com sérios problemas a resolver numa guerra com Espanha. Não é de se admirar portanto, que o Conse-

Guairá. Ameaçadas pelos castelhanos, essas famílias também teriam seus motivos para temer a nova dinastia bragantina. Caso permanecessem súditas do rei de Espanha, seus bens podiam ser confiscados na América portuguesa. Portanto, tinham interesse em escapar às soberania portuguesa e espanhola. "Por todas estas razões, os alvoroços dos anos 1640 em São Paulo ultrapassam a objeção estreita à Madri, para assumir um caráter mais amplo, antimetropolitano e anti-europeu" (ALENCASTRO, 1994, p. 99). 
lho Ultramarino, órgão então recém criado, não tenha dado atenção ao caso, ou minimizasse a sua importância. A contenda já estava resolvida, e Portugal tinha conflitos mais sérios a resolver na Europa, como a sua própria sobrevivência política ${ }^{14}$.

A aclamação de Amador Bueno poderia ser, desta forma, símbolo adequado de um momento histórico vivido no planalto paulista por volta de 1640. Mas não somente de São Paulo seiscentista, e é exatamente isto o que falta nas análises dos historiadores aqui contemplados. Pois a restauração da independência portuguesa significava também o advento de uma nova dinastia régia no cenário europeu e mundial, cujo poder efetivo, tanto no Reino quanto no ultramar, estava longe de se afirmar. O evento paulista de abril de 1641, assim, seria o contraponto para o acontecido em dezembro de 1640 em Portugal, considerando-se as características respectivas das duas partes envolvidas, vassalos vicentinos e dinastia bragantina: o rei frágil, os vassalos revoltosos. A presença do próprio Amador Bueno da Ribeira em Lisboa diante da Corte, apresentando o memorial dos paulistas em 1642 e o silêncio sobre o episódio, que só seria evocado na passagem para o século XVIII - já depois de um longo período de crise do poder monárquico em Portugal - ratificariam esta linha de raciocínio. Com efeito, a tradição inventada pelos paulistas fazia sentido.

${ }^{14}$ O Conselho Ultramarino foi criado em 1640. A guerra com a Espanha pela restauração da independência durou de 1640 até 1668 , feita de batalhas esparsas nas fronteiras. É fato que Portugal só conseguiu a vitória pelo enfraquecimento progressivo de Castela devido à Guerra dos Trinta Anos (1618-1648), e à luta com a França até 1659, pela revolta na Catalunha. Somente em 1669 a Santa Sé aceitou a causa lusitana. Por sua vez na América, os holandeses só foram expulsos de Pernambuco e capitanias vizinhas em 1654. Esses temas, que corroboram a idéia da fragilidade do império português por volta de 1640 e a gravidade do momento, são desenvolvidos em outros capítulos de minha tese (BENTES MONTEIRO, 1999).
Portanto, é na confluência de todos os fatores mencionados - a questão da mão-de-obra, do conflito com religiosos, entre famílias ou com autoridades governantes, sua posição no Império - que se busca o sentido da aclamação de Amador Bueno em 1641; não com o intuito de mensurar a sua importância para a história política do Brasil, mas sim de entendê-la como um elemento simbólico capaz de expressar um contexto histórico. Os conflitos ou insubordinações que foram aqui estudados ocorreram numa capitania mal dominada pelo poder régio, nunca efetivamente controlada e sequer visitada por seus donatários. Numa região onde o modo de vida de seus habitantes mais diferia da lógica assumida pelos portugueses em sua colonização na América. Também as lutas entre famílias e as indisposições com os governantes nos sugerem uma sociedade ainda não sedimentada em suas relações de poder. Desse modo, se tencionamos buscar uma relação entre a figura do rei como personificação do Estado e a ordem social na América portuguesa, não parece mero acaso que a primeira sublevação desafiadora do poder monárquico tenha ocorrido na capitania de São Vicente - e justamente a mais frontal, por ter substituído o corpo régio em outra personagem. Ela demonstraria de maneira exemplar que o corpo político do rei Bragança era algo ainda a ser construído na América, e que tal problemática se relacionava com o tema da Restauração, em Portugal ${ }^{15}$.

Em conclusivo, pode-se afirmar que a aclamação de Amador Bueno permaneceu presente na história bra-

\footnotetext{
${ }^{15}$ O historiador Alain Boureau criticou a obra de Ernst Kantorowicz, ao defender que a idéia da existência de dois corpos régios - um corpo físico, e um corpo místico ou político abrangendo todos os domínios do Reino - não era algo fornecido de modo consensual aos súditos pelos juristas Tudor ou pelos rituais funerários Valois, mas, sobretudo, uma construção teórica, uma intenção nem sempre aceita e por vezes contestada, mesmo nos casos inglês e francês. Proponho na tese a busca de outro paradigma para a compreensão da realeza portuguesa, mais próximo das discussões levantadas nos momentos
} 
sileira, a despeito de sua falta de consequiências, primeiramente como exemplo de obediência contraposta à perfídia espanhola. Esse ponto de vista aparecia nas memórias e linhagens setecentistas paulistanas que procuravam sublinhar a inocência dos vassalos paulistas e a honra do aclamado, ao mesmo tempo que buscavam a nobilitação de seus antepassados. Dessa forma, no século XIX, a aclamação de Amador Bueno foi associada à idéia de "tradição", ora para ser destacada como elemento significativo para a manutenção da ordem e da unidade territorial nacional, ora para ser desmerecida em função dos ataques que eram desferidos ao fidalguismo paulistano. Durante o século XX, houve uma primeira geração de historiadores que pintou esta exaltação do passado vicentino com novas tintas, de valores culturais e raciais. Essas inflexões podem ter conduzido ao relativo distanciamento do tema por parte de outros estudiosos contemporâneos, que no entanto contribuíram significativamente para a ampliação do seu contexto fundamental.

Os paulistas do século XVII foram grandes preadores de índios, mão-de-obra destinada basicamente às propriedades locais, cuja produção agrícola - sobretudo trigo e carne - era destinada ao abastecimento de outras regiões coloniais, não obstante a bem montada economia de subsistência no planalto. Em função da crescente demanda de outras capitanias litorâneas especialmente quando foram iniciadas as invasões holandesas - os paulistas tenderam a ampliar sua área de ação em busca de índios cativos pelo interior, entrando em maiores conflitos com os aldeamentos jesuítas no Paraguai. A Companhia de Jesus esmeravase em obter junto ao Papa e à coroa espanhola os

em que Portugal fez sua independência da Espanha, em especial na Restauração de 1640 , chave para a compreensão da identidade do poder régio dos Bragança no Reino e no ultramar americano, de acordo com a obra de Luís Reis Torgal (BOUREAU, 1988, KANTOROWICZ, 1981, e TORGAL, 1981 e 1982, 2 vol.). reforços para a interdição eficaz da escravidão indígena, base da economia paulistana, o que acabou culminando na expulsão desta ordem religiosa de alguns núcleos urbanos nas capitanias do sul. O elemento decisivo deste quadro repleto de tensões iria ser fornecido pelas relações dos paulistas com a autoridade governamental em exercício, suspeita de ser simpática à causa da Companhia. Desde há muito tempo, a Coroa vinha mantendo uma atitude ambígua para com o cativeiro indígena, dividida entre as pressões religiosas e as vantagens econômicas advindas de sua exploração, explícitas na capitania de São Vicente. No entanto, a publicação do breve do papa e a expulsão dos jesuítas de São Paulo colocava para todos um impasse. Há ainda uma explicação mais abrangente sobre o posicionamento de São Paulo na dinâmica de relações do império português, diferente do Rio de Janeiro, palco aliás de outra sublevação mencionada contra o governador Salvador Correia de Sá. Ao pautar sua prosperidade no tráfico ameríndio, São Paulo andava na contramão das expectativas lusitanas, caracterizadas pelo incentivo ao comércio de africanos, papel desempenhado pelo Rio de Janeiro em seus contatos com Angola. Em face das novas do Reino acerca do advento da nova dinastia portuguesa, diante das hesitações de governantes ultramarinos na aceitação do fato e do apoio jesuíta à causa da Restauração, parece plausível que os paulistas se tenham mostrado decididos na aclamação de seu próprio rei.

\section{Bibliografia}

ALENCASTRO, Luiz Felipe de. Os Lusos Brasileiros em Angola: Constituição do Espaço Econômico no Atlântico Sul (1550-1700). Tese de livre docência em história econômica apresentada ao Instituto de Economia da Universidade de Campinas. Campinas, 1994.

BERCÉ, Yves-Marie. Le Roi Caché. Paris, Fayard, 1990.

BETHENCOURT, Francisco e CURTO, Diogo Ramada (org.). A Memória da Nação. Lisboa, Sá da Costa, 1991.

BICALHO, Maria Fernanda Baptista. A Cidade e o Império: $O$ 
Rio de Janeiro na Dinâmica Colonial Portuguesa. Séculos XVII e XVIII. Tese de doutorado apresentada ao Departamento de História da Faculdade de Filosofia, Letras e Ciências Humanas da Universidade de São Paulo. São Paulo, 1997.

BOUREAU, Alain. Le Simples Corps du Roi. L'impossible sacralité des souverains français Xve-XVIIIe siècle. Paris, Éditions de Paris, 1988.

BOXER, Charles. Salvador de Sá e a Luta pelo Brasil e Angola. São Paulo, Companhia Editora Nacional / EDUSP, 1973.

BRÁSIO, Antônio. "O problema da sagração dos monarcas portugueses", in Anais da Academia Portuguesa de História. Lisboa, 1989, n.83, p.34-43.

CHARLEVOIX, Pierre François. Histoire du Paraguay. Paris, Didot-Giffart-Nyon, 1757.

ELLIS JÚNIOR, Alfredo. Amador Bueno e seu Tempo. São Paulo, Ind. Graf. Siqueira, 1948.

ELLIS JÚNIOR, Alfredo. Amador Bueno, o Rei de São Paulo. São Paulo, J. Fagundes, 1937.

FALAS DO TRONO (1823-1889). Rio de Janeiro, Imprensa Nacional/Câmara dos Deputados, 1889.

FRANÇA, Eduardo d'Oliveira. Portugal na Época da Restauração. São Paulo, Hucitec, 1997.

FRÉMONT, Armand. A Região, Espaço Vivido. Coimbra, Livraria Almedina, 1980.

HOLANDA, Sérgio Buarque de (org.). História Geral da Civilização Brasileira-A Época Colonial. São Paulo, DIFEL, 1985, 2 vol.

HOLANDA, Sérgio Buarque de. Caminhos e Fronteiras. São Paulo, Companhia das Letras, 1994.

HOLANDA, Sérgio Buarque de. Raízes do Brasil. Rio de Janeiro, José Olympio, 1986.

KANTOROWICZ, Ernst. The King's Two Bodies. Princeton, Princeton University Press, 1981.

LADURIE, Emmanuel Le Roy. O Estado Monárquico (14601610). São Paulo, Companhia das Letras, 1994.

LEITE, Aureliano. "Amador Bueno, sua vida e, em especial, o seu papel dentro da capitania de S.Vicente do Estado do Brasil, nos acontecimentos da Restauração da monarquia portuguesa", in Congresso do Mundo Português. Lisboa, Comissão Executiva dos Centenários, 1940, v.VII, t.II, p.549-567.
LEME, Pedro Taques de Almeida. Nobiliarquia Paulistana Histórica e Genealógica. São Paulo / Belo Horizonte, EDUSP / Itatiaia, 1980, t.I.

MADRE DE DEUS, Frei Gaspar da. Memórias para a História da Capitania de São Vicente. São Paulo / Belo Horizonte, EDUSP / Itatiaia, 1975.

MELLO, Evaldo Cabral de. O Nome e o Sangue. São Paulo, Cia. das Letras, 1989.

MONTEIRO, John Manuel. Negros da Terra. São Paulo, Cia. das Letras, 1995.

MONTEIRO, Rodrigo Bentes. O Rei no Espelho: A Monarquia Portuguesa e a Colonização da América (1640-1720). Tese de doutorado apresentada ao Departamento de História da Faculdade de Filosofia, Letras e Ciências Humanas da Universidade de São Paulo. São Paulo, 1999.

NOVAIS, Fernando A. Portugal e Brasil na Crise do Antigo Sistema Colonial. São Paulo, Hucitec, 1983.

PRADO, Paulo. Província e Nação. Paulística Retrato do Brasil. Rio de Janeiro, José Olympio, 1972.

SOUZA, Laura de Mello e. Motins, Revoltas e Revoluções na América portuguesa - Séculos XVIIXVIII. São Paulo, 1995, texto cedido à Unesco.

TAUNAY, Affonso d'Escragnolle. Amador Bueno e Outros Ensaios. São Paulo, Imprensa Oficial do Estado, 1943.

TAUNAY, Affonso d'Escragnolle. História Seiscentista da Vila de São Paulo. São Paulo, Tipografia Ideal - Heitor L. Canton, 1926,t.I (1600-1653).

TORGAL, Luís Reis. Ideologia Política e Teoria do Estado na Restauração. Coimbra, Biblioteca Geral da Universidade, 1981-1982, 2 vol.

VARNHAGEN, Francisco Adolfo de. Amador Bueno ou a Coroa do Brasil em 1641, drama épico-histórico americano. Madrid, Imprenta Del Atlas, 1858.

VARNHAGEN, Francisco Adolfo de. História Geral do Brasil. São Paulo / Belo Horizonte, EDUSP / Itatiaia, 1981, v.2.

VARNHAGEN, Francisco Adolfo de.. Vassalo Rei, melodrama heróico brasileiro em quatro atos e três quadros, respeitosamente dedicado à S.M. o Sr. D. Pedro II. Rio de Janeiro, Tipografia da Atualidade, 1864.

Endereço do Autor: Rua Barão de Itambi, 55 apto. 509 - CEP 22231-000 - Botafogo - Rio de Janeiro - RJ 